\title{
C14 and C16 acylcarnitines in newborns with orofacial clefts
}

\section{C14 i C16 acylokarnityny u noworodków z rozszczepem twarzoczaszki}

\author{
Margareta Budner', Iwona Ługowska², Ewa Sawicka¹, Piotr Fudalej ${ }^{3}$, Kamil K. Hozyasz ${ }^{4}$ \\ 1Department of Paediatric Surgery, Institute of Mother and Child, Warsaw, Poland \\ 2Department of Epidemiology, Institute of Mother and Child, Warsaw, Poland \\ 3Department of Orthodontics and Oral Biology, Radboud University Nijmegen Medical Centre, The Netherlands \\ ${ }^{4}$ Department of Paediatrics, Institute of Mother and Child, Warsaw, Poland
}

Prz Gastroenterol 2012; 7 (5): 276-280

DOI: $10.5114 /$ pg.2012.32065

Key words: cleft palate, acylcarnitines, risk factor, tandem mass spectrometry.

Słowa kluczowe: rozszczep podniebienia, acylokarnityny, czynnik ryzyka, tandemowa spektrometria mas.

Address for correspondence: Kamil K. Hozyasz, Department of Paediatrics, Institute of Mother and Child, 17 A Kasprzaka St, 01-211 Warsaw, Poland, e-mail: kamil.hozyasz@imid.med.pl

\begin{abstract}
:
Introduction: Non-syndromic cleft lip with or without cleft palate $(C L / P)$ is one of the most common malformations of the gastrointestinal tract; however, its aetiology is still unclear. Myristic and palmitic acids are key components of a typical Western diet. Some evidence was observed for increased $\mathrm{CL} / \mathrm{P}$ risk with the highest scores of maternal saturated fat intake. Acylcarnitines may regulate embryonic development.

Aim: Analyse associations of neonatal C14 and C16 acylcarnitines with $\mathrm{CL} / \mathrm{P}$ risk.

Material and methods: We performed a retrospective analysis of concentrations of C14 and C16 acylcarnitines obtained from a newborn screening programme. Concentrations of whole blood acylcarnitines were measured using tandem mass spectrometry (MS/MS). The study group consisted of 64 children with $\mathrm{CL} / \mathrm{P}$. One hundred and thirty healthy children without congenital anomalies served as controls. Classification and Regression Tree (CART) analysis was used to explore the influence of $\mathrm{C} 14$ and $\mathrm{C} 16$ acylcarnitines on the child's risk of being born with an orofacial cleft.

Results: The mean (SD) concentration of tetradecenoylcarnitine (C14:1) was lower in newborns with CL/P compared with controls: $0.157(0.053) \mu \mathrm{mol} / \mathrm{l}$ vs. $0.202(0.093) \mu \mathrm{mol} / \mathrm{l}, p<0.00002$, respectively. The CART selected two factors associated with $\mathrm{CL} / \mathrm{P}$ risk: a low level of tetradecenoylcarnitine $(<0.177 \mu \mathrm{mol} / \mathrm{l})$ and a high level of palmitoylcarnitine (> $4.955 \mu \mathrm{mol} / \mathrm{l})$.

Conclusions: The study provides initial data indicating a potential association between acylcarnitine profiles and CL/P risk. MS/MS can be considered as a promising investigation tool to better understand the biochemical background of orofacial clefts.
\end{abstract}

\section{Streszczenie}

Wprowadzenie: Niezespołowe rozszczepy wargi połączone lub nie z rozszczepem podniebienia (CL/P) są jednymi z najczęstszych malformacji przewodu pokarmowego, jednak ich etiologia jest mało poznana. Kwas mirystynowy i palmitynowy powszechnie wchodzą w skład zachodniej diety. Wykazano zależność pomiędzy podażą nasyconych kwasów tłuszczowych w diecie matki a ryzykiem wystąpienia CL/P u potomstwa. Acylokarnityny mogą przypuszczalnie regulować rozwój zarodka. Cel: Analiza powiązań pomiędzy C14 i C16 acylokarnitynami a ryzykiem wystąpienia $\mathrm{CL} / \mathrm{P}$.

Materiał i metody: Retrospektywnie analizowano wyniki oznaczeń stężenia C14 i C16 acylokarnityn w pełnej krwi w noworodkowym badaniu przesiewowym metodą tandemowej spektrometrii mas (MS/MS). Grupę badaną stanowito 64 pacjentów z CL/P. Do grupy kontrolnej zakwalifikowano 130 dzieci bez wad wrodzonych. Do badań dotyczących wpływu acylokarnityn na ryzyko urodzenia się dziecka z CL/P wykorzystano analizę drzewa decyzji CART.

Wyniki: Średnie stężenie \pm standardowe odchylenie tetradecenoilokarnityny (C14:1) było istotnie statystycznie mniejsze u pacjentów z CL/P niż w grupie kontrolnej $(0,157 \pm 0,053 \mu \mathrm{mol} / \mathrm{l}$ vs $0,202 \pm 0,093 \mu \mathrm{mol} / \mathrm{l}, p<0,00002)$. Wykorzystując analizę CART, zidentyfikowano małe stężenia tetradecenoilokarnityny $(<0,177 \mu \mathrm{mol} / \mathrm{l})$ i duże stężenia palmitoilokarnityny $(>4,955$ $\mu \mathrm{mol} / \mathrm{l})$ jako czynniki ryzyka urodzenia się dziecka z CL/P.

Wnioski: Przedstawione wyniki sugerują zależność pomiędzy homeostazą C14 i C15 acylokarnityn a ryzykiem wystąpienia CL/P. Tandemowa spektrometria mas stanowi obiecujące narzędzie badawcze w poznawaniu biochemicznego podłoża zaburzeń palatogenezy. 


\section{Introduction}

Non-syndromic cleft lip with or without cleft palate $(\mathrm{CL} / \mathrm{P})$ is one of the most common anomalies of the human gastrointestinal tract, with a birth prevalence of approximately 1-2 per 1000 . Relatively little is known about the causes of this condition, and there are no established strategies for reducing its occurrence [1]. Concordance among monozygotic twins ranges between $40 \%$ and $60 \%$, whereas it is approximately $5 \%$ among dizygotic twins. The lack of $100 \%$ concordance rates among monozygotic twins argues against genetic events alone being responsible for abnormal palatogenesis [1].

Acylcarnitine analysis of dried blood spots using tandem mass spectrometry (MS/MS) to detect disorders of fatty acid oxidation and some disorders of organic acid metabolism is one of the most important advances in neonatal screening [2]. MS/MS offers the possibility of multi-metabolite analyses in a single analytical run. During catabolism on the first days after an infant's birth, all of the transporters and enzymes required for fatty acid $\beta$-oxidation are highly induced. Talián et al. [3] have recently suggested extraordinarily active participation of carnitine in the intermediary metabolism in pregnancy. The newborn screening programme provided by our institute quantifies carnitines, which may reflect homeostasis of 14-carbon and 16-carbon fatty acids [2].

In experimental studies diets enriched in long fatty acids influence early embryonic development and pregnancy losses [4, 5]. In the food industry, myristic acid (a 14-carbon, straight-chain saturated fatty acid) is increasingly used as a multipurpose food additive and flavour adjuvant [6]. Both myristic acid and palmitic acid (a 16-carbon, straight-chain saturated fatty acid) have generally been considered to be pro-lipogenic and proatherogenic, and as key components of a typical Western diet, may be associated with increased risk of abnormal palatogenesis. It is interesting to note that Vujkovic et al. [7] recently demonstrated that mothers with the highest scores of saturated fat intake had an increased risk of having a child with an orofacial cleft.

\section{Aim}

Against this background, the aim of the present study was to investigate associations between newborn concentrations of $\mathrm{C} 14$ and C16 acylcarnitines and CL/P risk.

\section{Material and methods Study population}

Patients with isolated cleft lip with or without cleft palate attending our institution and unrelated healthy children of similar age - the patients of three local pri- mary care paediatricians - were considered for inclusion in the study. Inclusion criteria were as follows: (i) singleton pregnancy, (ii) gestational age at delivery $\geq 36$ weeks and/or birth weight $>2000$ g, which have long been recognized as important determinants of newborn health, (iii) delivery in the years 2004-2009 in hospitals located within the area covered by the MS/MS Newborn Screening Programme provided by our institution. Case eligibility was determined from detailed medical records. Finally, we performed a retrospective analysis of newborn MS/MS C14 and C16 acylcarnitine screening results of 64 children with CL/P and 130 healthy controls without congenital anomalies. All mothers were white Caucasians of Polish origin.

The study was designed and carried out observing the ethical principles established by the local Institutional Guidelines on Clinical Investigation.

\section{Mass spectrometry}

The dried blood spots ("Guthrie cards") were generally collected 3 days after the infant's birth. Discs were punched from dried blood spots on a filter paper. Specimens were extracted in pure methanol containing known concentrations of stable isotopically enriched carnitines. MS/MS analyses of the carnitines as butyrated esters were performed on a tandem mass spectrometer (SCIEX Api 2000, Concord, Canada) configured with liquid chromatography for sample handling. The working range was $0.005-150 \mu \mathrm{mol} / / \mathrm{l}$ of acylcarnitines.

\section{Statistical analysis}

Statistical methods for analysis of C14 and C16 acylcarnitine concentrations as the continuous variable included the $t$-test and Spearman correlation analysis. The non-parametric and non-algebraic Classification and Regression Tree (CART) analysis was used to explore the influence of C14 and C16 acylcarnitines on the child's risk of being born with an orofacial cleft. CART is a useful tool to explore the interactions between an undesired outcome and its determinants. Beginning with the first (a root) node, CART finds the best possible variable to split the node into two daughter nodes. This process is then repeated until all variables have been exhausted or the terminal nodes are homogeneous [8]. Statistical significance was interpreted as $p$ values $<0.05$. The data set was analysed with SPSS, version 16.0 (SPSS Polska Sp. z o.o., Krakow, Poland).

\section{Results}

Slightly more case newborns were females (48\%) compared with the control group (42\%), $p>0.05$. Mean gestational age at delivery of cases and controls was 
Table I. Whole blood C14 and C16 carnitine ester profiles in $\mathrm{CL} / \mathrm{P}$ patients and controls (mean $\pm \mathrm{SD}$, $\mu \mathrm{mol} / \mathrm{l})$

Tabela I. Profile C14 i C16 acylokarnityn w petnej krwi u pacjentów z CL/P i noworodków bez wad wrodzonych (średnia $\pm S D ; \mu \mathrm{mol} / \mathrm{l}$ )

\begin{tabular}{|c|c|c|}
\hline Biochemical name (short name) & $\begin{array}{l}\text { Cases } \\
(n=64)\end{array}$ & $\begin{array}{l}\text { Controls } \\
(n=130)\end{array}$ \\
\hline $\begin{array}{l}\text { Tetradecanoylcarnitine (C14) } \\
\text { (Myristoylcarnitine) }\end{array}$ & $0.308 \pm 0.085$ & $0.329 \pm 0.103$ \\
\hline Tetradecenoylcarnitine (C14:1) & $0.157 \pm 0.053^{a}$ & $0.202 \pm 0.093$ \\
\hline Tetradecadienylcarnitine (C14:2) & $0.057 \pm 0.039$ & $0.062 \pm 0.030$ \\
\hline $\begin{array}{l}\text { Hydroxytetradecanoylcarnitine } \\
(\mathrm{C} 14-\mathrm{OH})\end{array}$ & $0.026 \pm 0.014$ & $0.028 \pm 0.015$ \\
\hline $\begin{array}{l}\text { Hydroxytetradecenoylcarnitine } \\
(\mathrm{C} 14: 1-\mathrm{OH})\end{array}$ & $0.037 \pm 0.016$ & $0.039 \pm 0.031$ \\
\hline $\begin{array}{l}\text { Hexadecanoylcarnitine (C16) } \\
\text { (Palmitoylcarnitine) }\end{array}$ & $5.015 \pm 1.183$ & $4.864 \pm 1.382$ \\
\hline Hexadecenoylcarnitine (C16:1) & $0.420 \pm 0.130$ & $0.459 \pm 0.209$ \\
\hline $\begin{array}{l}\text { Hydroxyhexadecanoylcarnitine } \\
(\mathrm{C} 16-\mathrm{OH})\end{array}$ & $0.043 \pm 0.024$ & $0.046 \pm 0.021$ \\
\hline $\begin{array}{l}\text { Hydroxyhexadecenoylcarnitine } \\
(\mathrm{C} 16: 1-\mathrm{OH})\end{array}$ & $0.054 \pm 0.022$ & $0.050 \pm 0.021$ \\
\hline בחט & & \\
\hline
\end{tabular}

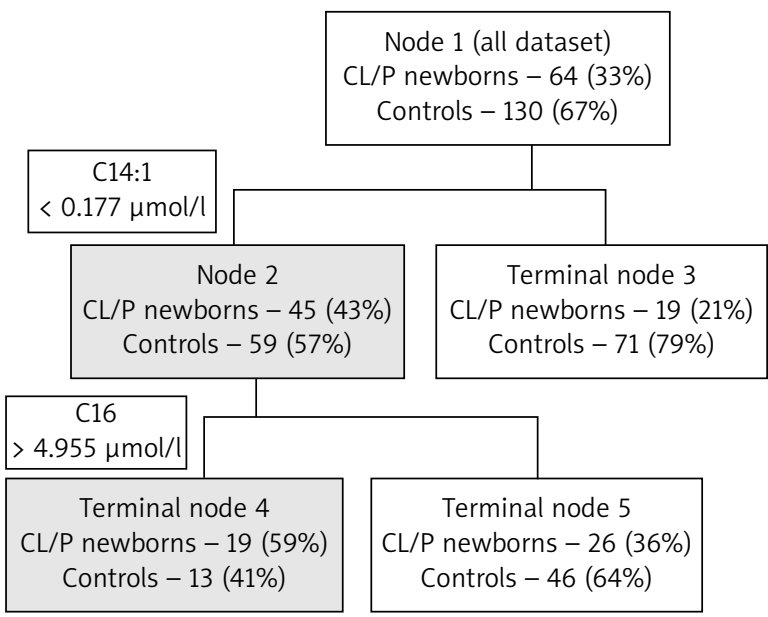

Fig. 1. Tree diagram of the best model from CART analysis

Ryc. 1. Diagram najlepszego modelu uzyskanego $w$ analizie CART

the same (39 weeks). Birth weights of CL/P newborns were a mean of $120 \mathrm{~g}$ lower than those in unaffected children $(p>0.05)$. The mean (SD) concentration of tetradecenoylcarnitine (C14:1) was lower in newborns with $\mathrm{CL} / \mathrm{P}$ compared with newborns without congenital anomalies: 0.157 (0.053) $\mu \mathrm{mol} / \mathrm{l}$ vs. 0.202 (0.093) $\mu \mathrm{mol} / \mathrm{l}$, $p<0.00002$, respectively. We could not demonstrate a difference in the concentrations of the other analysed acylcarnitines between cases and controls (Table I).

There were no significant correlations between concentrations of acylcarnitines and clinical variables such as birth weight or gestational age at delivery.

The CART identified two factors associated with CL/P risk: a low level of tetradecenoylcarnitine (C14:1) and a high level of palmitoylcarnitine (C16). The best tree from CART is shown in Figure 1.

\section{Discussion}

In the present study, we highlight the problems of 14-carbon and 16-carbon fatty acid metabolism in abnormal palatogenesis. Our results provide unprecedented evidence that a low concentration of C14:1-carnitine and high C16-carnitine concentration in newborns may be associated with increased risk of being born with CL/P. This finding hold promise for better definition of the mechanisms of abnormal palatogenesis, and improving clinical diagnostic models. However, currently, the mechanisms leading to the observed metabolic derangement are not understood and we have no evidence that the reduction of C14:1-carnitine and elevation of C16carnitine have any detrimental effect on palatogenesis. Changes in acylcarnitine profile can be secondary to several clinical conditions [2,9]. It is noteworthy that maternal diabetes is a well-known risk factor for orofacial clefts and C14:1-carnitine appears to play an important role in metabolic responses to carbohydrate challenge of the organism [10].

Covalent attachment of lipid moieties to proteins is an essential modification found on many proteins. It is interesting to note that so far low serum myo-inositol has been recognized as a risk factor for orofacial clefts and neural tube defects [11, 12]. Moreover, maternal dexamethasone exposure, which affects phosphatidylinositol metabolism in human embryonic palatal mesenchyme, can lead to CL/P in offspring [13]. Recent studies have provided many new insights into the regulation and biology of major forms of lipid modification with phosphatidyl-inositol, isoprenylation, amino (N)terminal myristoylation, and the most versatile posttranslational addition of palmitic acid and other saturated fatty acids, such as myristic acid, and unsaturated long-chain fatty acids (so-called palmitoylation) [14]. Myristoylation and the chemically related palmitoylation influence a wide spectrum of structural and functional features of proteins $[15,16]$. Myristoylation is essential for the development and survival of mammals and has implications in diseases as diverse as malaria and cancer [17]. Cycles of palmitoylation and depalmitoylation occur in a regulated manner for many receptor and signalling proteins that mediate growth and patterning 
during organogenesis. Attachment of palmitate is important for signalling molecules, such as Hedgehog $(\mathrm{Hh})$ and Sonic Hedgehog (Shh) $[15,18]$. It was suggested that an interaction between environmental risk factors and the $\mathrm{Hh}$ signalling pathway may contribute to the occurrence of orofacial clefts in humans [19]. Our findings suggest that the metabolic pathway of C14 and C16 fatty acids is disturbed in CL/P-affected patients; however, it is impossible to conclude whether myristic and palmitic acids or their metabolites directly affect palatogenesis. Further studies are warranted to validate these presumptions.

In contrast to low C14:1-carnitine, an elevated concentration of this acylcarnitine serves as a disease specific marker of very long-chain acyl-CoA dehydrogenase deficiency (VLCAD) [20]. Highly increased C16-carnitine is the primary marker used to identify carnitine palmitoyltransferase type II (CPT-II) deficiency [9]. It therefore seems reasonable to test VLCAD and CPT2 as CL/P candidate genes.

There are no previously published clinical association studies of the C14 and C16 acylcarnitines investigated in the present report with CL/P risk, and so we are unable to compare our results with data from other studies. Interestingly, in Finland Erkkillä et al. [21] investigated the serum fatty acid profile in 10-year-old children with orofacial clefts. The mean myristic acid level was significantly higher in patients who were born with cleft lip in comparison to children with isolated submucous cleft palate. The authors suggested differences in fatty acid metabolism in different groups of patients with orofacial clefts [21].

Our results might be influenced by the sample size, which may not be large enough to detect modest differences of acylcarnitine levels in the cases and the control group. There are some other limitations to consider. The assessments of acylcarnitines were undertaken only in newborns, which may have diminished the possibility of finding teratologically pertinent feto-maternal changes. The study design is retrospective and we lacked the ability to access additional information on newborn feeding and maternal diet. Despite the potential limitations, this study also had some notable strengths. The investigated population is ethnically homogeneous, and mostly omnivorous. Data of acylcarnitine assessments were from the population-based MS/MS Newborn Screening Programme, but we were able to establish the phenotypic cleft type in all cases.

\section{Conclusions}

Assessments of acylcarnitines based on MS/MS can be considered as a promising investigation tool to bet- ter understand the biochemical background of orofacial clefts.

\section{References}

1. Teitelbaum JE. Mouth and esophagus. Congenital anomalies. In: Walker's pediatric gastrointestinal disease. Kleinman RE, Sanderson IR, Goulet O, et al (ed.). BC Decker Inc, Hamilton 2008; 7-17.

2. Rinaldo P, Tortorelli S, Matern D. Recent development and new applications of tandem mass spectrometry in newborn screening. Curr Opin Pediatr 2004; 16: 427-33.

3. Talián GC, Komlósi K, Decsi T, et al. Determination of carnitine ester patterns during the second half of pregnancy, at delivery, and in neonatal cord blood by tandem mass spectrometry: complex and dynamic involvement of carnitine in the intermediary metabolism. Pediatr Res 2007; 62: 88-92.

4. Thangavelu G, Colazo MG, Ambrose DJ, et al. Diets enriched in unsaturated fatty acids enhance early embryonic development in lactating Holstein cows. Theriogenology 2007; 68: 949-57.

5. Yanes O, Clark J, Wong DM, et al. Metabolic oxidation regulates embryonic stem cell differentation. Nat Chem Biol 2010; 6: 411-7.

6. Burdock GA, Carabin IG. Safety assessment of myristic acid as a food ingredient. Food Chem Toxicol 2007; 45: 517-29.

7. Vujkovic M, Ocke MC, van der Spek PJ, et al. Maternal Western dietary patterns and the risk of developing a cleft lip with or without a cleft palate. Obstet Gynecol 2007; 110: 378-84.

8. Breiman L, Friedman JH, Olshen RA, Stone CJ. Classification and regression trees. Wadsworth, Belmont 1984.

9. Zytkovicz TH, Fitzgerald EF, Marsden D, et al. Tandem mass spectrometric analysis for amino, organic, and fatty acid disorders in newborn dried blood spots: a two-year summary from the New England Newborn Screening Program. Clin Chem 2001; 47: 1945-55.

10. Zhao X, Peter A, Fritsche J, et al. Changes of the plasma metabolome during an oral glucose tolerance test: is there more than glucose to look at? Am J Physiol Endocrinol Metab 2009; E384-93.

11. Krapels IP, van Rooij IA, Wevers RA, et al. Myo-inositol, glucose and zinc status as risk factors for non-syndromic cleft lip with or without cleft palate in offspring: a case-control study. BJOG 2004; 111: 661-8.

12. Groenen PM, Peer PG, Wevers RA, et al. Maternal myo-inositol, glucose, and zinc status is associated with the risk of offspring with spina bifida. Am J Obstet Gynecol 2003; 189: 1713-9.

13. Grove RI, Willis WD, Pratt RM. Dexomethasone affects phophatidylinositol synthesis and degradation in cultured human embryonic cells. Biochem Biophys Res Commun 1983; 110: 200-7.

14. Bijlmakers MJ, Marsh M. The on-off story of protein palmitoylation. Trends Cell Biol 2003; 13: 32-42.

15. Chen MH, Li YJ, Kawakami T. Palmitoylation is required for the production of a soluble multimeric Hedgehog protein complex and long-range signaling in vertebrates. Genes Dev 2004; 18: 641-59.

16. Resh MD. Palmitoylation of ligands, receptors, and intracellular signaling molecules. Sci STKE 2006; 359: re14. 
17. Wright MH, Heal WP, Mann DJ, Tate EW. Protein myristoylation in health and disease. J Chem Biol 2010; 3: 19-35.

18. Buglino JA, Resh MD. Hhat is a palmitoylacyltransferase with specifity for N-palmitoylation of Sonic Hedgehog. J Biol Chem 2008; 283: 22076-88.

19. Lipinski RJ, Bushman W. Identification of Hedgehog signaling inhibitors with relevant human exposure by small molecule screening. Toxicol in Vitro 2010; 24: 1404-9.

20. Liebig M, Schmik I, Wendel U, et al. Neonatal screening for very long-chain acyl-CoA dehydrogenase deficiency: enzymatic and molecular evaluation of neonates with elevated C14:1-carnitine levels. Pediatrics 2006; 118: 1065-9.

21. Erkkilä AT, Isotalo E, Pulkkinen J, Haapanen ML. Association between school performance, breast milk intake and fatty acid profile of serum lipids in ten-year-old cleft children. J Craniofac Surg 2005; 16: 764-9. 